\title{
Klaudia Reikowska
}

Uniwersytet Ekonomiczny we Wrocławiu

e-mail: klaudia.reikowska@ue.wroc.pl

\section{CHARAKTERYSTYKA KONKURENCYJNOŚCI CHIŃSKICH PRZEDSIĘBIORSTW DZIAŁAJĄCYCH POPRZEZ CHIŃSKĄ PLATFORME ALIEXPRESS NA RYNKU EUROPEJSKIM}

\section{CHARACTERISTIC COMPETITIVENESS \\ OF CHINESE COMPANIES OPERATING THROUGH \\ CHINESE ALIEXPRESS PLATFORM ON THE EUROPEAN MARKET}

DOI: $10.15611 / \mathrm{e} 21.2017 .4 .07$

JEL Classification: $\mathrm{O} 15$

Streszczenie: Sprzedaż dóbr prowadzona za pośrednictwem Internetu w ramach działania różnego rodzaju platform i serwisów aukcyjnych jest coraz bardziej powszechna. Rynek europejski jest $\mathrm{w}$ tym aspekcie znakomitym miejscem dokonywania transakcji w perspektywie potencjalnego przedsiębiorcy poszukującego rynku zbytu. Jednym z doskonałych przykładów prezentujących atrakcyjność tego rodzaju serwisów jest chińska platforma sprzedażowa AliExpress, która w Europie zyskuje ogromną grupę odbiorców. Przedsiębiorstwa chińskie, stanowiące bazę oferentów funkcjonujących na tym portalu, muszą sprostać wielu wyzwaniom w aspekcie gwarancji jakości, sposobu i czasu dostawy, ale także stoją przez wyzwaniem budowania swej konkurencyjności w zakresie podnoszenia innowacyjności, budowania marki i zaufania oraz ukierunkowania swej działalności na wdrażania i absorbowanie nowych technologii. Celem artykułu jest scharakteryzowanie konkurencyjności chińskich przedsiębiorstw działających na rynku europejskim poprzez chińską platformę sprzedażową AliExpress. Dzięki analizie różnego rodzaju aspektów konkurencyjności oraz sposobu działania tych podmiotów zostaną wyciągnięte wnioski weryfikujące hipotezę zakładającą, iż przedsiębiorstwa chińskie działające na rynku europejskim poprzez platformę sprzedażową AliExpress podnoszą swą konkurencyjność i zmieniają stereotypowe myślenie o produktach i towarach chińskich utożsamianych z niską jakością i ceną.

Słowa kluczowe: przedsiębiorstwo chińskie, platforma sprzedażowa, konkurencja, jakość, cena.

Summary: The sale of goods carried out by the Internet as part of the operation of various types of auction platforms and services is becoming more and more common. The European market is in this aspect an excellent place for transactions in the perspective of a potential entrepreneur seeking a market. One of the great examples presenting the attractiveness of 
this type of services is the Chinese AliExpress sales platform, which in Europe is gaining a huge audience. Chinese enterprises, which are the base of bidders functioning on this portal, have to face many challenges in the aspect of quality guarantee, delivery method and time and are challenged to build their competitiveness in terms of increasing innovation, brand building and trust as well as focusing their activities on implementation and absorbing new technologies. The purpose of the article is to characterize the competitiveness of Chinese enterprises operating on the European market through the Chinese AliExpress sales platform. Thanks to the analysis of various aspects of competitiveness and the way these entities operate, conclusions will be drawn verifying the hypothesis assuming that Chinese enterprises operating on the European market through the AliExpress sales platform raise their competitiveness and change the stereotypical thinking about Chinese products and goods identified with low quality and price.

Keywords: Chinese company, sales platform, competition, quality, price.

\section{Platforma sprzedażowa AliExpress. Grupa Alibaba}

Nowoczesność, innowacyjność i nowe technologie to ważne czynniki wpływające na transakcje kupna i sprzedaży zachodzące we współczesnym świecie. Odbywają się one już nie tylko w tradycyjnych formach i miejscach, jakimi były targi, sklepy lub bazary, ale dokonywane są w cyberprzestrzeni, czyli w Internecie. Branża e-commerce, która tworzy nowoczesne platformy sprzedażowe typu Business to Business (B2B) oraz Business to Consumer (B2C) są doskonałą formą prezentowania ofert biznesowych i sprzedażowych, do których odbiorcy mają dostęp przez dwadzieścia cztery godziny na dobę. Jest to ogromnie rozbudowany system, który służy do wspierania procesu zakupu i sprzedaży, ale także dokonywania kontroli zamówień, wyszukiwania i generowania najlepszych ofert, pewnej kategoryzacji dokonywanych wyborów oraz niezwykle silnej komunikacji między podmiotami biznesowymi, takimi jak dostawcy, kontrahenci oraz dystrybutorzy [Lewicki 2012, s. 18].

$\mathrm{Na}$ rynku europejskim istnieje wiele platform sprzedażowych, które prężnie działając, osiągają wiele zysków. W Polsce najbardziej znaną platformą sprzedażową jest allegro.pl, które w 2016 r. zostało sprzedane funduszom Cinven, Premira i Mid Europa Partners. Warto wspomnieć, iż transakcja ta została uznana za jedną z 10 największych transakcji w całej branży e-commerce ${ }^{1}$. Inne znane platformy aukcyjne i sprzedażowe to ebay.de działające na terenie Niemiec, ale także amazon. com oraz walmart.com funkcjonujące w Stanach Zjednoczonych oraz asos.com lub uk.edib.net, które znajdują swoich odbiorców na terenie Wielkiej Brytanii. Do grona zaprezentowanych pionierów w zakresie oferentów zakupów online dołączyła bardzo silnie i prężnie działająca platforma sprzedażowa AliExpress, należąca do grupy Alibaba. Skupia ona bardzo wiele gałęzi e-commerce na terenie Chińskiej Re-

1 http://www.pomorska.pl/strefa-biznesu/wiadomosci/a/sprzedaz-allegro-serwis-poszedl-za-ponad3-mld-dolarow,10742374/ (dostęp: 10.09.2017). 
publiki Ludowej. Są to przede wszystkim portale zakupowe, do których należą m.in. AliExpress, Alibaba, Taobao oraz Tmall, ale także inne serwisy płatności elektronicznych Alipay, wszelkie rozwiązania mobilne oraz usługi cloud computingu. Są one coraz powszechniejsze i dotyczą tak zwanego przetwarzania w chmurze, a więc nabycia możliwości korzystania z programu bez konieczności zakupu jego licencji. Jest to pewnego rodzaju formuła standaryzacji programów komputerowych, mająca na celu zwiększenie ich przystępności dla większego grona odbiorców² ${ }^{2}$ Na rys. 1 przedstawiono graficzne ujęcie firm należących do spółki Alibaba.

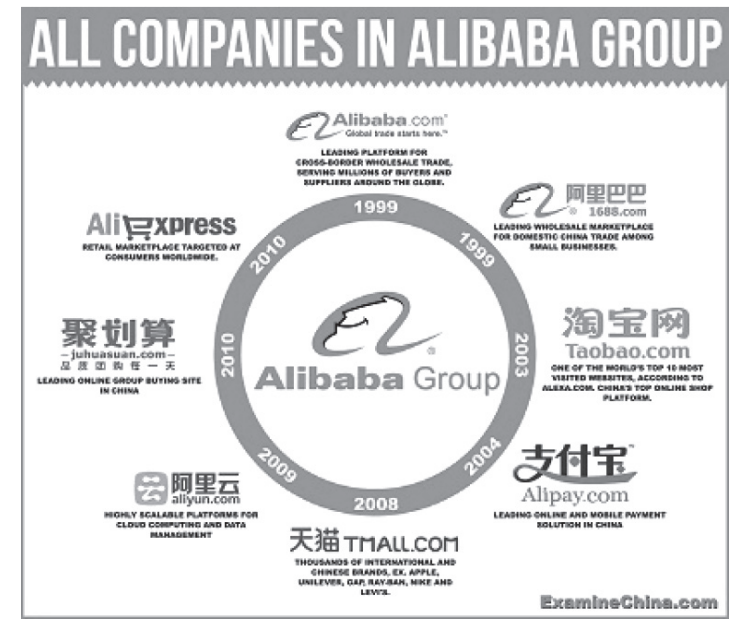

Rys. 1. Firmy i przedsiębiorstwa należące do grupy Alibaba

Źródło: [https://www.chinskiraport.pl/blog/10-faktow-o-alibaba-group/ (dostęp: 10.09.2017)].

Grupa Alibaba została założona w 1999 r. przez nauczyciela języka angielskiego Jaka Ma. Postanowił on wraz, z osiemnastoma innymi inwestorami, uruchomić platformę alibaba.com, która dedykowana była chińskim przedsiębiorcom chcącym rozszerzyć swoją działalność w ramach prowadzenia sklepów online. Obecnie grupa ta należy do największych serwisów internetowych, z których korzystają klienci nie tylko biznesowi, ale również indywidualni. Ostatnie dane pokazują, iż grupa Alibaba kontroluje niemal $80 \%$ całego chińskiego rynku e-commerce ${ }^{3}$. Obecnie firma ta posiada swe biura w Europie - na terenie Włoch, Niemiec, a także Francji. Pełnią one ważną funkcję pośredników pomiędzy największą chińską platformą sprzedażową, która działa na starym kontynencie, a sprzedawcami i odbiorcami, którzy chcieliby wejść na chiński rynek internetowy.

\footnotetext{
${ }^{2}$ http://computingcloud.pl/pl/cloud-przewodnik/czym-jest-cloud-computing (dostęp: 10.09.2017).

${ }^{3}$ https://inwestor.newseria.pl/newsy/rynki-zagraniczne/debiut_alibaby_moze_byc,p1902415441 (dostęp: 11.09.2017).
} 
Powszechność, konkurencyjność oraz atrakcyjność tego rodzaju platform wynika przede wszystkim z ogromnego wyboru produktów - każdy potencjalny konsument zawsze znajdzie coś dla siebie. Ponadto ważna jest konkurencyjna cena, ale także oszczędność czasu związana z samym wyborem i zakupem danego produktu, bez konieczności wychodzenia $\mathrm{z}$ domu. Do niedawna grupa Alibaba była liderem w całej branży e-commerce i jednym z największych konkurentów grupy Amazon, która z kolei prężnie działa na terenie Stanów Zjednoczonych. Podmiot ten odebrał pozycję lidera opisywanej spółce z powodu braku zaufania inwestorów, jakie wynikało $\mathrm{z}$ handlu podróbkami na tejże platformie.

Zmiana zarządzania platformą, a także ostatnia konferencja B2B oraz B2C, corocznie organizowana przez branżę e-commerce, na której swe przemówienie zaprezentował jej założyciel Jack Ma, zmieniła tę sytuację, gdyż prognozy oraz dane świadczą o tym, iż grupa Alibaba sprawnie i szybko zmierza ku temu, aby w najbliższej przyszłości odzyskać czołową pozycję lidera. Wartość rynkowa grupy Alibaba sięgnęła w lipcu 2017 r. wartość 392,7 mld dolarów. Na rys. 2 zaprezentowano zmiany wartości spółki w ciągu ostatnich dwóch lat.
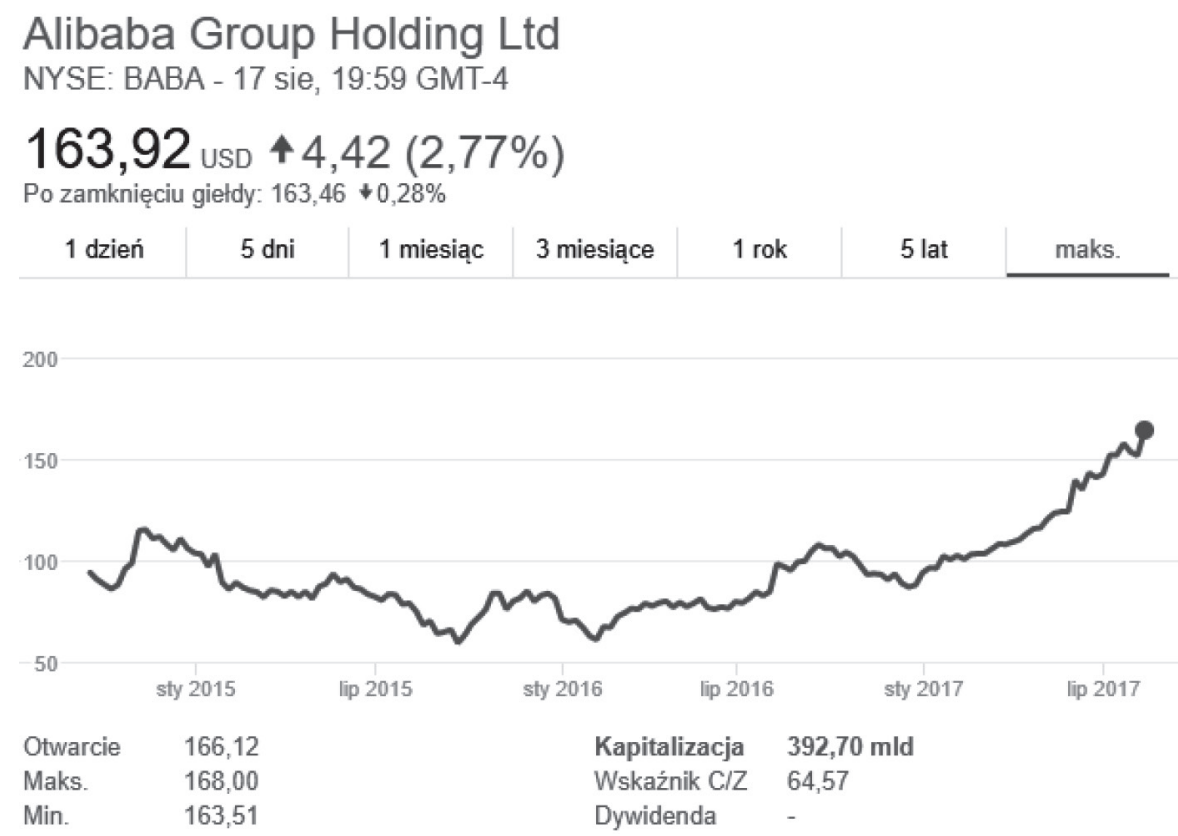

Rys. 2. Wartość grupy Alibaba w latach 2015-2017

Źródło: [http://www.spidersweb.pl/2017/08/alibaba-aliexpress-amazona.html (dostęp: 11.09.2017)].

Jak wynika z wykresu na rys. 2, wartość spółki od stycznia 2016 r. stopniowo rośnie, po niewielkim spadku spowodowanym handlem podróbkami i bezpośrednio 
z tym powiązanym spadku zaufania inwestorów. Dane z lipca 2017 r. przedstawiają rekordową wartość grupy Alibaba.

\section{Aspekty konkurencyjności chińskich przedsiębiorstw dzialających na platformie AliExpress}

Specyfika działania chińskich przedsiębiorstw na platformie sprzedażowej AliExpress jest bardzo prosta i atrakcyjna zarówno dla klientów indywidualnych, jak i dla małych i średnich przedsiębiorstw, które dokonują na tej platformie niewielkich zakupów hurtowych. Serwis jest dostępny w języku angielskim oraz thumaczony, choć czasem nieudolnie, na niemal 100 języków świata. Dzięki temu potencjalny klient nie ma żadnych problemów ze znalezieniem produktu, który go interesuje, aspekt ten ułatwia także sam przebieg transakcji. Na platformie istnieje możliwość zakupu niemal wszystkiego - począwszy od ubrań, kosmetyków, sprzętów sportowych, hobbystycznych, kolekcjonerskich po sprzęt elektroniczny, dekoracje oraz inne produkty.

Najsilniejszymi wyznacznikami w zakresie konkurencyjności przedsiębiorstw działających w Chińskiej Republice Ludowej są przede wszystkim stopy procentowe, koszty pracy, ale także korzyści skali i kursy walutowe. W aspekcie zmian zachodzących na rynku światowym Chiny potrzebują jednak nieco innego spojrzenia na konkurencyjność i innych sposobów jej osiągania. Obecnie firmy, które działają na serwisie AlExpress, w aspekcie konkurencyjności są silne ze względu przede wszystkim na różnorodność produktów oferowanych w jednym miejscu. Element ten jest doskonale dopracowany w kontekście nie tylko językowym, ale także związanym z dokładnością wyszukiwarki i precyzyjnością odnajdywania wpisywanych w niej fraz. Kolejny ważny element to fakt, iż przedsiębiorstwa chińskie działające na tej platformie nie posiadają sklepów stacjonarnych, co znacznie obniża ostateczną cenę zakupu lub sprzedaży danego towaru. Do niedawna chiński towar utożsamiany był przede wszystkim z chińską (niską) ceną oraz, niestety, z bardzo niską jakością oferowanych produktów. Jednak w ostatnim czasie następuje odejście od opisywanego stereotypu, chińskie przedsiębiorstwa bowiem doskonale zdają sobie sprawę, iż konkurencyjność ewoluuje, a niezadowolony klient nie dokona ponownego zakupu na aukcji, jego niezadowolenie zaś przyczyni się do znacznego obniżenia przyszłych zysków przedsiębiorstw.

Kolejny ważny aspekt w zakresie konkurencyjności przedsiębiorstw chińskich na rynku europejskim stanowi zwiększenie stawek celnych, którego dokonano w roku 2008 m.in. w Polsce. Wówczas stawki te zostały zwiększone do 150 euro, dzięki temu produkty wpływające na teren Rzeczpospolitej Polskiej do tej wartości są zwolnione z opłat celnych, co nie podwyższa ceny kupowanego produktu. Ponadto istotnym aspektem w zakresie wymiany tego rodzaju towarów są unijne przepisy, które dotyczą podatku VAT. W przypadku Polski do wartości 22 euro nie trzeba uiszczać podatku VAT, jednak ze względu na dostosowanie się do dyrektyw 
i rozporządzeń unijnych należy przestrzegać prawa europejskiego mówiącego, iż wartość tego rodzaju przesyłek nie może być wyższa niż 45 euro. Ponadto w legislacji Unii Europejskiej opisywany jest status zwany ,gift”. Wiąże się to z faktem, iż wszelkiego rodzaju przesyłki wpływające na teren Unii Europejskiej posiadające tego rodzaju status są prezentem skierowanym $\mathrm{w}$ formie prywatnej do jego obiorcy i nie stanowią przedmiotu transakcji kupna i sprzedaży, co nie do końca wiąże się $\mathrm{z}$ jawnością i klarownością $\mathrm{w}$ aspekcie prawnym dokonywania tego typu transakcji.

Niezwykle ważnym aspektem związanym z konkurencyjnością chińskich przedsiębiorstw na rynku europejskim działających na platformie AliExpress jest moda na tego typu zakupy i funkcjonowanie portali społecznościowych, które tworzą swego rodzaju reklamę i zachęcają do korzystania z takiej platformy sprzedażowej. Dotyczy to tak zwanych grup zakupowych działających przede wszystkim poprzez portal Facebook, na którym klienci wymieniają się wzajemnymi recenzjami zakupywanych towarów, opisują ich jakość, cenę, szybkość przesyłki, kontakt ze sprzedawcą oraz wzajemnie polecają je sobie lub ostrzegają się przed nieuczciwymi sprzedawcami. W ten sposób budowane są - w sposób nie do końca świadomy w kontekście chińskich przedsiębiorstw - zaufanie i bezpieczeństwo związane $\mathrm{z}$ aspektem dokonywania zakupów poprzez tego rodzaju platformy sprzedażowe. W ostatnim czasie podmioty te doceniły jednak rolę takich grup, zachęcając je różnego rodzaju promocjami i upustami, skierowanymi specjalnie do nich jako wąskiej grupy odbiorców.

Bardzo ważną kwestią jest także sporo możliwości dokonania reklamacji związanych z wadliwością towarów lub innych problemów z dostawą. Towarzyszy temu założenie, że klient jest najważniejszy. Z pomocą przychodzi tutaj opcja zwana confirm good received ${ }^{4}$, która warunkuje otrzymanie środków finansowych za zakupiony towar dopiero $\mathrm{w}$ momencie, kiedy klient potwierdzi dostawę otrzymanego produktu. Wcześniej przesłane przez klienta środki są jakby zawieszone. Jeżeli przesyłka dotarła, konsument potwierdził dostawę, jednak nie jest zadowolony z jakości produktu lub towar posiada wadę, ma on możliwość złożenia reklamacji i założenia tak zwanego sporu, w którym zostanie ustalona forma zadośćuczynienia lub rekompensaty dla klienta, który nie był zadowolony z dokonanego zakupu. Ważnym aspektem jest także dbałość Chińczyków o pozytywne komentarze, tak zwane feedbacki, a więc opinie wraz z realnym zdjęciem otrzymanego towaru, które warunkują wielkość sprzedaży. Większa ilość tego typu informacji sprzyja zaufaniu i buduje poczucie bezpieczeństwa wśród nowych klientów oraz wpływa na korzyści skali związane z dokonywanymi zakupami. Stanowią one także cenne źródło informacji.

Istotnym elementem w kontekście dokonywania zakupów z Chińskiej Republiki Ludowej jest czas dostawy, który zazwyczaj jest gwarantowany w przedziale od 25 do 60 dni. Wydawać by się mogło, iż jest to bardzo długi okres, jednak nie wynika on do końca z przyczyn, które mogłyby leżeć w gestii przedsiębiorstw chińskich. Od ubiegłego roku istnieje dość duży problem z dostawą tego rodzaju paczek na teren

\footnotetext{
${ }^{4}$ Potwierdź odbiór towaru.
} 
Rzeczypospolitej Polskiej ze uwagi na tzw. włoski strajk polskich strażników celnych, którzy nie zgadzają się na włączenie do Krajowej Administracji Skarbowej5. W związku z tym ich mozolna praca sprawia, iż paczki z Chin tkwią w Urzędzie Celnym w Zabrzu, a klienci otrzymują je znacznie później. Ważnym elementem jest także koszt i sposób dostawy. W bardzo wielu przypadkach przesyłki są darmowe lub ich koszt jest bardzo niewielką kwotą, co wpływa na to, iż cena jest nadal bardzo atrakcyjna. Potencjalny konsument ma możliwość śledzenia przesyłki na terenie Chin, a także rejestrowania przesyłki, która zostaje wysłana za pośrednictwem China Post Registered Air Mail lub China Post Ordinary Small Packet Plus.

Zaprezentowane aspekty konkurencyjności przedsiębiorstw chińskich, które realizowane są poprzez formy i sposoby ich działania na tego rodzaju platformie, uzupełnia fakt, iż do tej pory cała konkurencyjność firm działających na rynku chińskim opierała się na produkcji towarów, które były bardzo pracochłonne, a ostatecznie osiągały niską wartość dodaną. Zmiana perspektyw i polityki państwa wpłynęła na to, iż obecnie konkurencyjność nie ogranicza się jedynie do tradycyjnie wykorzystywanych metod oraz obszarów, a wprost przeciwnie, na terenie tego państwa absorbowane są nowe, zagraniczne technologie, a także są wdrażane i wykorzystywane projekty innowacyjne, dzięki czemu firmy te mają możliwość konkurowania na rynkach światowych [Łopacińska 2014, s. 107]. Chińczycy zrozumieli, że konkurowanie tylko i wyłącznie niskimi cenami nie wpłynie na osiągnięcie przez nich trwałej konkurencyjności na rynku światowym. Stawia się zatem na budowanie i realizację strategii firmy, które oparte są na przyjęciu pewnego rodzaju standardów, a także na przywiązanie wagi do wartości niematerialnych, takich jak reputacja, podnoszenie wiarygodności, ale również budowanie zaufania do marki czy koncentracja na wprowadzaniu innowacji, sprawnej komunikacji oraz inwestowaniu w kapitał ludzki, który musi się rozwijać i zwiększać swoje zasoby wiedzy. Powyższe starania i założenia wpływają na to, że chińskie przedsiębiorstwa doceniane są w ogólnoświatowych rankingach konkurencyjności. Nie da się jednak ukryć, iż w ramach struktury działania tego rodzaju platformy istnieją różnego rodzaju niejasności i wątpliwości. Przykładem jest oznakowanie paczek, którego celem jest uśpienie czujności celników sprawdzających towary wysyłane z Chin. Dotyczy to zaprezentowanego na rys. 3 znaku CE, często błędnie odczytywanego jako „Conformité Européenne” tłumaczonego „Zgodny z dyrektywami Unii Europejskiej”. W rzeczywistości oznacza on „China Export”. Oczywiście fakt, iż znaki te są bliźniaczo podobne, nie jest przypadkiem, a gdy liczba przesyłek jest ogromna, może stanowić element odwracający uwagę i osłabiający czujność celników.

\footnotetext{
http://www.polsatnews.pl/wiadomosc/2016-06-08/protest-celnikow-przeciw-wlaczeniu-ichsluzby-do-krajowej-administracji-skarbowej/ (dostęp: 12.10.2017).
} 


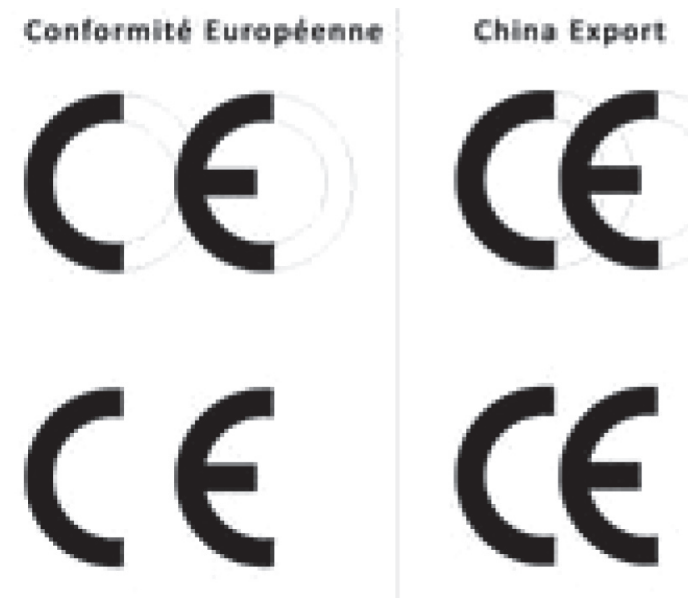

Rys. 3. Oznakowanie paczek wpływających na teren UE z Chin

Źródło: [http://www.bankier.pl/wiadomosc/Zakupy-z-Chin-jak-kupowac-przez-AliExpress-7218906.html (dostęp: 13.10.2017)\}.

Innym dość powszechnym precedensem, z którym platforma sprzedażowa AliExpress stara się walczyć, jest tzw. problem aukcji ukrytych, na których sprzedawane są podróbki towarów znanych światowych marek. Chcąc zrozumieć to zjawisko, warto przyjrzeć się fotografii na rys. 4 .

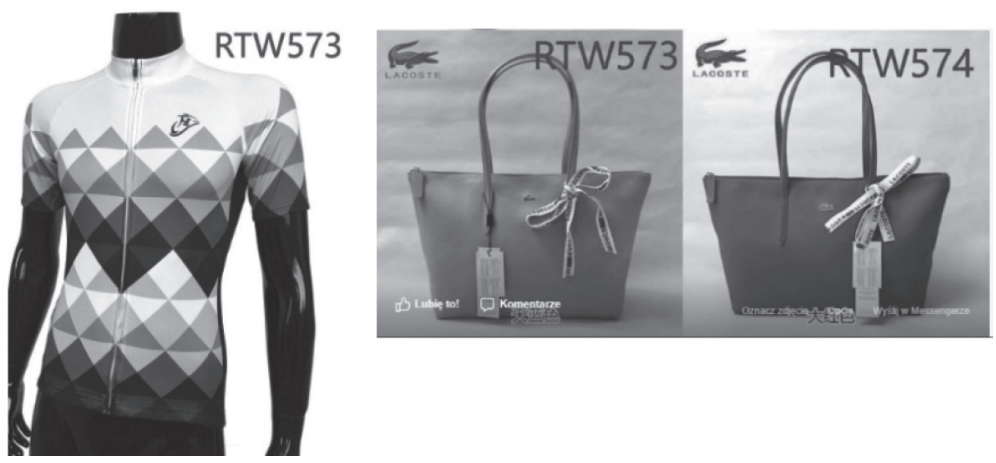

Rys. 4. Problem aukcji ukrytych na platformie AliExpress

Źródło: [AliExpress.com, facebook.pl].

Po lewej stronie prezentowany jest przedmiot aukcji - T shirt, który jest sprzedawany i oznakowany za pomocą kodu RTW573 w cenie 24,99dol., co przy obecnym kursie (październik 2017 r.) daje kwotę 89,90 zł. W rzeczywistości jednak klient dokonuje zakupu podróbki torebki firmy Lacoste, której kod jest dokładnie identyczny 
jak torebki zamieszczonej obok na fotografii. Wartość rynkowa oryginalnej torby tej firmy to 369 zł. Osoby, które dokonywały tego typu zakupów, za pośrednictwem komentarzy na różnego rodzaju portalach społecznościowych informują, że właściwie kupując oryginalny produkt, również jesteśmy świadomi tego, iż jest on produkowany na terenie Chin, jednak cena ma tutaj na tyle duże znaczenie, że klienci mimo wszystko decydują się na zakup tego produktu na tzw. aukcjach ukrytych.

Przedsiębiorstwa chińskie w kształtowaniu swej przewagi konkurencyjnej mogą liczyć na ogromną pomoc państwa i jego polityki, ponieważ obecnie wspiera ono ich działalność. Dzięki wdrażaniu nowych technologii i kreowaniu informacji dąży się do zmian w zarządzaniu i działalności badawczo-rozwojowej, a także w kształtowaniu silnych i pozytywnych relacji między partnerami biznesowymi i klientami, co ma znaczenie w kontekście podejmowania wyzwań związanych z rosnącą konkurencyjnością. Dzięki tym działaniom, jak pokazują najnowsze sondaże i rankingi dotyczące konkurencyjności, przedsiębiorstwa chińskie w tym aspekcie radzą sobie bardzo dobrze.

\section{Podsumowanie}

Podsumowując charakterystykę działania chińskich przedsiębiorstw na rynku europejskim w kontekście platformy sprzedażowej AliExpress, warto podkreślić, iż w lipcu 2017 r. w grupie Alibaba zarejestrowanych było 466 mln aktywnych kupujących $^{6}$. Dla porównania portal sprzedażowy Allegro w październiku 2016 r. posiadał tych użytkowników tylko 20 milionów. Na serwisie AliExpress odnotowuje się ciągły wzrost wartości dokonywanych transakcji. Średnia kwota jednorazowego zakupu w ostatnich latach wzrosła o niemal $250 \%$, co dowodzi większego zainteresowania, ale także wzrostu zaufania do chińskich przedsiębiorców ${ }^{7}$. Niezwykle ważnym aspektem jest także wzrost poczucia bezpieczeństwa zawieranych transakcji i związana z tym dbałość o jakość i uczciwość chińskich sprzedawców, którzy zachęcają konsumentów do dokonywania nowych zakupów o znacznie większej wartości. Chińskie przedsiębiorstwa stawiają także na szybki i przyjazny kontakt z kupującymi, oferując zniżki i kupony, dzięki którym cała platforma bardzo zyskuje na atrakcyjności. Niewątpliwie jednym z najważniejszych aspektów działalności platformy jest fakt, iż konsument ma pewność, że jeśli towar nie spełni jego oczekiwań, będzie uszkodzony, wadliwy lub niezgodny z opisem, może on podjąć wspomniany wcześniej spór i wraz z pracownikami platformy AliExpress odzyskać całość lub część pieniędzy, a także wymienić towar na nowy.

Trafnym podsumowaniem zaprezentowanych rozważań będzie przypomnienie słów założyciela grupy Alibaba Jacka Ma, uznawanego za najbogatszego Chińczyka

\footnotetext{
${ }^{6} \mathrm{https}: / /$ www.spidersweb.pl/2017/08/alibaba-aliexpress-amazona.html (dostęp: 14.10.2017).

${ }^{7}$ https://allinside.pl/ (dostęp: 14.10.2017).
} 
i mądrego przedsiębiorcę, związanych z podejściem do prowadzenia firmy i przedsiębiorstwa, przywoływanych na różnego rodzaju konferencjach i wystąpieniach. Często podkreśla on, iż siła przedsiębiorstwa to przede wszystkim brak pieniędzy, a nie jego nadmiar, zwłaszcza w początkowej fazie rozwoju firmy, ponieważ przedsiębiorca jest bardziej czujny, ostrożny i podejmuje bardziej racjonalne decyzje, opierając się na tym, iż nie do końca czuje się bezpieczny. Bardzo ciekawym podejściem jest także jego opinia, iż nie zawsze chodzi o liczbę zatrudnionych osób w firmie, ale przede wszystkim o ich doświadczenie, mądrość oraz zaangażowanie w wykonywaną pracę. Podkreśla on, że inwestowanie w kapitał ludzki jest dla chińskich przedsiębiorców coraz ważniejsze, dzięki czemu także zwiększają oni swoją konkurencyjność na rynku nie tylko europejskim, ale i globalnym ${ }^{8}$.

Chińskie przedsiębiorstwa działające na platformie sprzedażowej AliExpress dążą zatem do podnoszenia swej konkurencyjności na rynku europejskim i globalnym. Mimo różnego rodzaju wątpliwości i niejasności starają się budować swoją markę, kreować pozytywny wizerunek, zbudować strategię i zarządzanie, które przyniesie zyski i zwiększy ich konkurencyjność. Starają się też odchodzić od tradycyjnego nastawienia tylko i wyłącznie skoncentrowanego na korzyści skali, wynikające z dużej ilości sprzedanych dóbr za niską cenę, utożsamianych jednak z niską jakością. Chińscy przedsiębiorcy stawiają na dbałość o aspekt związany z jakością sprzedawanych produktów tak, aby zwiększać zaufanie i zadowolenie swoich klientów. Takie podejście, a także skupienie się na aspekcie innowacyjności, wdrażaniu nowych technologii oraz podnoszeniu wiarygodności związanej z transakcjami kupna i sprzedaży przyczyniają się do tego, że w rankingach konkurencyjności chińskie przedsiębiorstwa stają się jeszcze silniejsze, nastawione na rozwój i umacnianie się na rynku światowym.

\section{Literatura}

AliExpress.com, facebook.pl. http://computingcloud.pl/pl/cloud-przewodnik/czym-jest-cloud-computing (dostęp: 10.09.2017). http://www.bankier.pl/wiadomosc/Zakupy-z-Chin-jak-kupowac-przez-AliExpress-7218906.html (dostęp: 13.10.2017).

http://www.polsatnews.pl/wiadomosc/2016-06-08/protest-celnikow-przeciw-wlaczeniu-ich-sluzby-dokrajowej-administracji-skarbowej/ (dostęp: 12.10.2017).

http://www.pomorska.pl/strefa-biznesu/wiadomosci/a/sprzedaz-allegro-serwis-poszedl-za-ponad-3-mlddolarow,10742374/ (dostęp: 10.09.2017).

http://www.spidersweb.pl/2017/08/alibaba-aliexpress-amazona.html (dostęp: 11.09.2017).

https://allinside.pl/ (dostęp: 14.10.2017).

https://businessinsider.com.pl/rozwoj-osobisty/kariera/jak-byc-liderem-w-biznesie-jack-ma-zalozycielalibaba-group/eln7780 (dostęp: 14.10.2017).

8 https://businessinsider.com.pl/rozwoj-osobisty/kariera/jak-byc-liderem-w-biznesie-jack-ma-zalozyciel-alibaba-group/eln7780 (dostęp: 14.10.2017). 
https://inwestor.newseria.pl/newsy/rynki-zagraniczne/debiut_alibaby_moze_byc,p1902415441 (dostęp: 11.09.2017).

https://www.chinskiraport.pl/blog/10-faktow-o-alibaba-group/ (dostęp: 10.09.2017).

Lewicki M., 2012, Instrumenty tworzenia wartości dla klienta w handlu elektronicznym, Wydawnictwo Uniwersytetu Ekonomicznego w Poznaniu, Poznań.

Łopacińska K., 2014, Źródła konkurencyjności przedsiębiorstw na przykładzie wybranych firm chińskich, Zeszyty Naukowe Uniwersytetu Szczecińskiego, nr 823, Szczecin. 